\title{
Phytomass and quality of yellow passion fruit seedlings under salt stress and silicon fertilization
}

\author{
IFederal University of Campina Grande, Pombal, Brazil \\ ${ }^{2}$ Federal Rural University of the Semi-arid, Caraúbas, Brazil \\ ${ }^{3}$ Federal University of Campina Grande, Campina Grande, Brazi \\ *Corresponding author, e-mail: genilsondiniz02@gmail.com
}

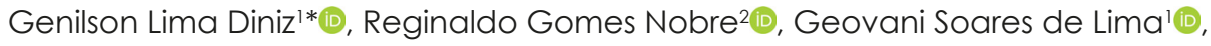

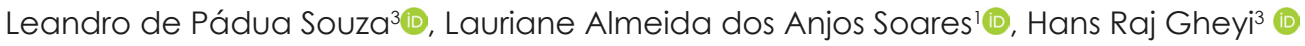

\begin{abstract}
The semiarid region of Northeastern Brazil is characterized by long drought periods, and the use of saline waters appears as an alternative for the expansion of irrigated areas. Associated with the use of these waters, silicon fertilization constitutes an important attenuator of salt stress. In this perspective, this study aimed to evaluate the phytomass production and quality of the passion fruit cultivar 'Gigante Amarelo' grown with saline water and silicon fertilization. The experiment was conducted in a plant nursery belonging to the Center of Agrifood Science and Technology, in the municipality of Pombal-PB. A completely randomized block design in a $5 \times 5$ factorial scheme was used, referring to five levels of electrical conductivity of the irrigation water $(0.3,1.0,1.7$, 2.4, and $3.1 \mathrm{dS} \mathrm{m}^{-1}$ ) and five doses of silicon fertilization (0;25;50;75, and $100 \mathrm{~g}$ of potassium silicate/plant), with four replications and two plants per plot. The phytomass accumulation (leaves, stem, and roots), as well as the total dry phytomass, shoot dry phytomass, root/shoot ratio, and the quality index of Dickson were evaluated. The data obtained were subjected to the F-test at 0.01 and 0.05 level of probability. The electrical conductivity of water from $0.3 \mathrm{dS} \mathrm{m}^{-1}$ caused the decrease of phytomass production in seedlings of the passion fruit cultivar 'Gigante Amarelo', although it is possible to produce good quality passion fruit seedlings with water salinity up to $3.1 \mathrm{dS} \mathrm{m}^{-1}$. The doses of silicon fertilization mitigated the effect of salt stress on the root/shoot ratio of plants of the passion fruit cultivar 'Gigante Amarelo'.
\end{abstract}

Keywords: saline waters, attenuating, silicon, tolerance

\section{Introduction}

The passion fruit originated in Tropical America. This fruit species presents a wide economic expression in Brazil. Among the best-known species with greater commercial application, the yellow passion fruit can be highlighted (Passiflora edulis f. flavicarpa), which is cultivated in almost the entire national territory, mainly in family farming (Meletti, 2011).

Passiflora species are mainly cultivated for the nutritional and the pharmacological characteristics (sedative, diuretic, antidiarrheal, stimulant, tonic, and in the treatment of hypertension) and food properties of the juice, seeds, and peel, being rich in pectin, niacin, iron, calcium, and phosphorus. However, the main importance of the passion fruit is related to human food, in which it can be consumed either in natura or in the processing of juices, refreshments, sweets, jellies, ice-cream, and liqueurs.
Although the Northeast region of Brazil is highlighted for comprising most of the national passion fruit production, the excess of salts in water sources has severely compromised the formation of seedlings in this crop (Ayers \& Westcot, 1999).

According to Ayers \& Westcot (1999), the passion fruit crop is sensitive to salt stress, with a threshold salinity level of $1.3 \mathrm{dS} \mathrm{m}^{-1}$ in saturation extract of soil. Salinity hinders plant growth as a function of the osmotic effects, restricting the availability and absorption of nutrients, causing toxicity due to the accumulation of specific ions,

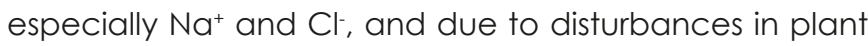
nutrition, directly affecting the plant metabolism and growth (Freire et al., 2010).

There are several studies (Cavalcante et al., 2009; Moura et al., 2017; Andrade et al., 2018) conducted with passion fruit under saline conditions, although studies that evaluate seedling formation under salt stress and 
silicon fertilization are still incipient. Silicon is important for the maintenance of the photosynthetic rate, increase of stomatal conductance, decrease of the transpiration rate through the mechanisms of control of the opening and closing of stomata, improvement of plant architecture, besides being associated to the increase of the antioxidant defense capacity in several plant species. In this manner, the use of Si can be employed as an alternative to minimize the negative effect of salts in crops.

One of the main forms for the determination of seedling quality for planting is through the Dickson quality index (DQI), in which the higher the DQI, the better is the quality of the seedling produced, since it relates the robustness and the balance of biomass distribution in the plant (Oliveira et al., 2013).

In this context, this study aimed to evaluate the phytomass production and quality of the passion fruit cultivar 'Gigante Amarelo' seedlings grown with saline water and silicon fertilization.

\section{Material and Methods}

The experiment was conducted under greenhouse conditions, in the facilities of the Center of Agrifood Science and Technology of the Federal University of Campina Grande, in the municipality of Pombal-PB, located at 6 $6^{\circ} 47^{\prime} 3^{\prime \prime}$ S, 37049' 15" W, and elevation of $193 \mathrm{~m}$.

A randomized block design was adopted, in a 5 x 5 factorial scheme, referring to five levels of electrical conductivity of the irrigation water - ECW $(0.3,1.0,1.7$,
2.4, and $\left.3.1 \mathrm{dS} \mathrm{m}^{-1}\right)$ and five doses of silicon fertilization (0, $25,50,75$, and $100 \mathrm{~g}$ of silicon per plant), with two plants per plot and four replications, totaling 200 experimental units. The water salinity levels were based on a study conducted by Andrade et al. (2019). The ECw levels were obtained by the addition of sodium chloride ( $\mathrm{NaCl}$ ) in the supply water of the municipality of Pombal-PB 10.3 $\mathrm{dS} \mathrm{m}^{-1}$ ) observing the ratio between the ECW and salt concentration (mg L-1 $=640 \times \mathrm{ECW}$ ) (Richards, 1954).

Potassium silicate was employed for the fertilization doses, which is composed of multiminerals: selenium, vanadium, calcium, zinc, and phosphorus, among several trace elements, with $50 \%$ of $\mathrm{SiO}_{2}$ and $4 \%$ of $\mathrm{K}_{2} \mathrm{O}$.

The studied crop was the passion fruit cultivar 'Gigante Amarelo', a hybrid adapted to elevations that vary from 376 to $1100 \mathrm{~m}$ and can be planted at any time of the year, destined for the fruit and industry market. This variety presents bright yellow fruits, with weight varying from 120 to $350 \mathrm{~g}$. The pulp represents nearly $40 \%$ of the fruit, with a marked yellow color, a high percentage of vitamin $\mathrm{C}$, and ${ }^{\circ}$ Brix between 13 and 15 degrees.

The research began with the sowing, which was performed in plastic bags with dimensions of $15 \times 20 \mathrm{~cm}$ and capacity for 1,250 mL, filled with a 2:1:1 ratio of a substrate, based on volume (soil, sand, and cured bovine manure). The physical and chemical characteristics of the soil (Table 1) used for seedling production were obtained according to the methodology proposed by Teixeira et al. (2017).

Table 1. Physical and chemical characteristics of the soil used in the experiment, before the application of the treatments.

\begin{tabular}{|c|c|c|c|c|c|c|c|c|c|}
\hline \multicolumn{10}{|c|}{ Chemical characteristics } \\
\hline \multirow{2}{*}{$\begin{array}{c}\mathrm{pH}\left(\mathrm{H}_{2} \mathrm{O}\right) \\
(1: 2.5)\end{array}$} & \multirow{2}{*}{$\begin{array}{c}O M \\
\text { dag } k^{-1}\end{array}$} & \multirow{2}{*}{$\begin{array}{c}\mathrm{P} \\
\left(\mathrm{mg} \mathrm{kg}^{-1}\right)\end{array}$} & $\mathrm{K}^{+}$ & $\mathrm{Na}^{+}$ & $\mathrm{Ca}^{2+}$ & $\mathrm{Mg}^{2+}$ & $\mathrm{H}^{+}+\mathrm{Al}^{3+}$ & ESP & \multirow{2}{*}{ 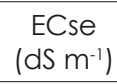 } \\
\hline & & & \multicolumn{5}{|c|}{$\ldots$} & $\%$ & \\
\hline 7.00 & 3.80 & 11.99 & 0.38 & 0.09 & 2.42 & 5.84 & 0.00 & 1.05 & 0.75 \\
\hline \multicolumn{10}{|c|}{ Physical characteristics } \\
\hline \multicolumn{3}{|c|}{ Size fraction $\left(\mathrm{g} \mathrm{kg}^{-1}\right)$} & \multicolumn{3}{|c|}{ Water content (kPa) } & \multirow[b]{2}{*}{ AW } & \multirow{2}{*}{$\begin{array}{c}\text { Total } \\
\text { porosity } \\
\%\end{array}$} & $A D$ & PD \\
\hline Sand & Silt & Clay & class & $\begin{array}{c}33,42 \\
\ldots \ldots \ldots \ldots . . .\end{array}$ & $\begin{array}{c}1519,5 \\
\text { dag } \mathrm{kg}^{-1}\end{array}$ & & & \multicolumn{2}{|c|}{--- $\left(\mathrm{kg} \mathrm{dm}^{-3}\right)^{----}$} \\
\hline 853.00 & 130.70 & 16.30 & LS & 11.60 & 4.23 & 6.93 & 47.23 & 1.50 & 2.69 \\
\hline
\end{tabular}

The soil moisture content was raised to field

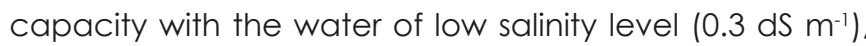
through which water was applied into the bags until occurring free drainage. Irrigation was daily performed by manually applying the water of the respective treatment, taking as reference the process of drainage lysimetry (Bernardo et al., 2006). The volume applied at each irrigation was determined by the difference between the volume applied and the volume drained in the previous irrigation, added by a 15\% leaching fraction applied every 20 days. The application of the saline levels began at 30 DAS and was daily performed until 60 DAS.

Two seeds of the passion fruit cultivar 'Gigante Amarelo' were sown per bag. After the seedling emergence, the thinning of the plants was performed, allowing only one plant per bag of $10 \mathrm{~cm}$ height.

The silicon doses were applied diluted via irrigation water, beginning at 30 DAS and performed 
weekly, totaling 4 applications until 60 DAS, according to the treatments, weekly application $0,6.25,12.5,18.75$, and $25 \mathrm{~g}$ of $\mathrm{Si}$ (potassium silicate: $50 \% \mathrm{SiO}_{2}$ and $4 \% \mathrm{~K}_{2} \mathrm{O}$ ) per plant.

The fertilization with nitrogen and potassium was weekly applied, and for the potassium fertilization, the content of the element already in the potassium silicate was considered. Phosphorus was applied as basal dose, according to Santos (2001). Urea, MAP and potassium chloride were used as the source of nitrogen, phosphorus and potassium, respectively.

The fertilization with NPK was performed by using $100 \mathrm{mg}$ of $\mathrm{N} \mathrm{kg}^{-1}$ of soil, $150 \mathrm{mg}$ of $\mathrm{K}_{2} \mathrm{O} \mathrm{kg}^{-1}$ of soil, and 300 mg of $\mathrm{P}_{2} \mathrm{O}_{5} \mathrm{~kg}^{-1}$ of soil. The following contents were applied per plant: $0.217 \mathrm{~g}$ of urea, $1.4 \mathrm{~g}$ of monoammonium phosphate, and $0.56 \mathrm{~g}$ of potassium chloride divided into 4 applications at intervals of 7 days, via fertigation starting 20 days after sowing.

The micronutrient applications were performed weekly, at $30 \mathrm{DAS}$, using $0.5 \mathrm{~g}$ of Quimifol ${ }^{\circledR}$ per liter (Cavalcanti, 2008). During the conduction of the experiment, the agronomical and phytosanitary practices recommended for the crop were performed, such as pest control and removal of tendrils.

The effects of the treatments on the passion fruit seedlings were analyzed at 60 days after sowing (DAS), a period in which the seedlings would be ready for transplanting to the field, by evaluating the phytomass accumulation (leaves, stem, and roots). The plants were cut close to the soil, separated into leaves, stem, and roots, placed separately in properly identified paper bags, and put to dry in a forced-air circulation oven at $65^{\circ} \mathrm{C}$, until obtaining constant weight; afterward, these were weighed in a precision balance, determining the leaf dry phytomass (LDP), stem dry phytomass (StDP), root dry phytomass (RDP), whose sum resulted in the total dry phytomass (TDP).

The dry phytomass of aerial part (DPAP) were also determined along with the root/shoot (R/S) ratio, and the Dickson quality index (DQI). The DPAP was obtained by the sum of the LDP + StDP. The DQI of the seedlings was determined through the formula by Dickson et al. (1960), described by the equation below:

$$
\mathrm{DQI}=\frac{(\mathrm{TDP})}{(\mathrm{PH} / \mathrm{SD})+(\mathrm{DPAD} / \mathrm{RDP})}
$$

In which:

$\mathrm{DQI}=$ Dickson Quality Index, $\mathrm{PH}=$ plant height $(\mathrm{cm})$, $\mathrm{SD}=$ stem diameter $(\mathrm{mm}), \mathrm{TDP}=$ total dry phytomass ( $\mathrm{g}$ plant $\left.^{-1}\right)$, DPAP $=$ dry phytomass of aerial part $\left(g_{\text {plant }}{ }^{-1}\right)$, and RDP = root dry phytomass (g plant).

The data obtained in this research were subjected to the F-test at 0.01 and 0.05 level of probability in order to perform the analysis of variance. When a significant effect of the treatments occurred, the means of the variables were subjected to polynomial regression for the silicon doses and saline levels. The statistical analyses were performed in the SISVAR software, Version 5.6 (Ferreira, 2011).

\section{Results and Discussion}

According to the analysis of variance, there was a significant effect of the saline levels (Table 2) for the leaf dry phytomass (LDP), stem (StDP), roots (RDP), and in the dry phytomass of aerial part (DPAP) of the passion fruit plants, at 60 DAS. The silicon doses significantly affected only the stem dry phytomass (StDP). There was no interaction of the SL x SD factors for any of the variables analyzed.

Table 2. Summary of the analysis of variance for the leaf dry phytomass (LDP), stem dry phytomass (StDP), root dry phytomass (RDP), and dry phytomass of aerial part (DPAP) of plants of the passion fruit cultivar 'Gigante Amarelo' grown under different salinity levels of the irrigation water and silicon doses, at 60 days after sowing (DAS).

\begin{tabular}{lccccc}
\hline \multirow{2}{*}{ Source of variation } & \multirow{2}{*}{ DF } & \multicolumn{4}{c}{ Mean squares } \\
\cline { 3 - 5 } & & LDP & StDP & RDP & DPAP \\
\hline Saline levels (SL) & 4 & $5.21^{*}$ & $1.30^{*}$ & $0.76^{* *}$ & $11.02^{*}$ \\
Linear regression & 1 & $19.41^{*}$ & $4.63^{*}$ & $2.70^{*}$ & $42.94^{*}$ \\
Quadratic regression & 1 & $0.78^{\text {ns }}$ & $0.50^{\text {ns }}$ & $0.28^{\text {ns }}$ & $0.03^{\text {ns }}$ \\
Silicon doses (SD) & 4 & $0.43^{\text {ns }}$ & $0.63^{* *}$ & $0.17^{\text {ns }}$ & $0.72^{\text {ns }}$ \\
Linear regression & 1 & $2.59^{* *}$ & $0.87^{* *}$ & $1.59^{*}$ & $6.46^{*}$ \\
Quadratic regression & 1 & $0.41^{\text {ns }}$ & $0.19^{\text {ns }}$ & $0.21^{\text {ns }}$ & $0.04^{\text {ns }}$ \\
Interaction (SL x SD) & 16 & $1.28^{\text {ns }}$ & 0.42 ns & $0.26^{\text {ns }}$ & $2.55^{\text {ns }}$ \\
Blocks & 3 & $0.31^{\text {ns }}$ & $0.05^{\text {ns }}$ & $0.09^{\text {ns }}$ & $0.13^{\text {ns }}$ \\
Residue & 72 & 0.39 & 0.16 & 0.13 & 0.59 \\
CV (\%) & & 23.18 & 21.17 & 22.33 & 16.64 \\
\hline
\end{tabular}

$n s, * * *$, respectively not significant, significant at $\mathrm{p}<0.05$ and $\mathrm{p}<0.01$ : DF - Degree of freedom: CV - Coefficient of variation. 
The leaf dry phytomass of the passion fruit (Figure 1A) decreased linearly with the increase in water salinity, obtaining a decline of $12.90 \%$ per unit increment of the ECW. By comparing the leaf dry phytomass of the plants irrigated with ECW of $3.1 \mathrm{dS} \mathrm{m}^{-1}$ in relation to those subjected

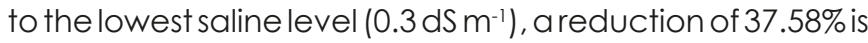
verified in the LDP. The decrease in phytomass production may be related to changes in the photosynthetic rate, in which an energy shift occurs, which is directed to growth for the activation and maintenance of the metabolic activity associated to tolerance mechanisms to salinity, such as the maintenance of membrane integrity and the regulation of the transportation and ionic distribution in several organs in the interior of the cells (Souza et al., 2016).

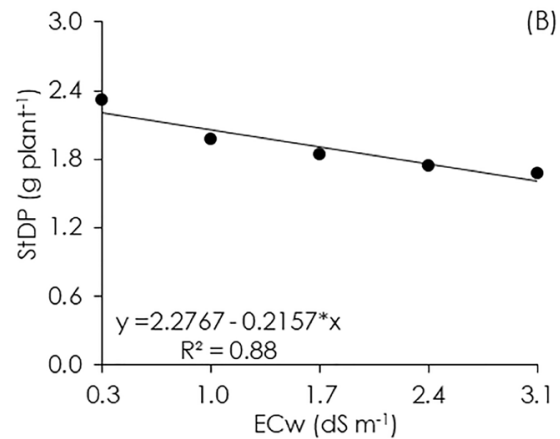

(C)

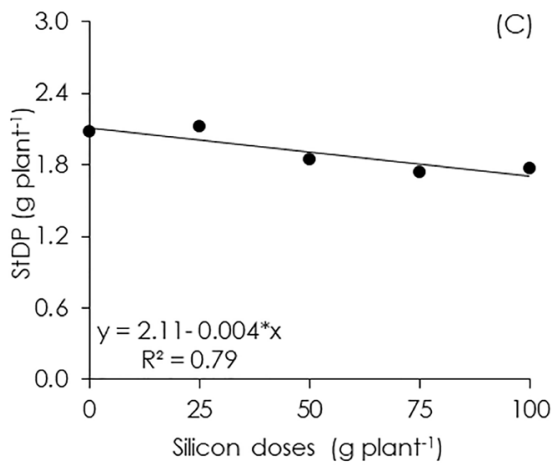

Figure 1. Leaf dry phytomass - LDP (A), stem dry phytomass - StDP (B) in seedlings of the passion fruit cultivar 'Gigante Amarelo' as a function of water salinity levels - ECW, and stem dry phytomass - StDP (C) as a function of silicon doses, at 60 days after sowing.

Likewise, the stem dry phytomass (Figure 1B) exhibited a linear decreasing behavior as the saline levels in the irrigation water were increased, with a decrease of $9.47 \%$ per unitary increment of the ECW, that is, a decrease of $27.30 \%$ ( $\left.0.60 \mathrm{~g} \mathrm{plant}^{-1}\right)$ in the plants that received the

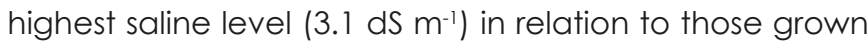
under the lowest saline level $\left(0.3 \mathrm{dS} \mathrm{m}^{-1}\right)$. Similar results were found in a study performed by Nascimento et al. (2017) with the passion fruit crop subjected to the ECW of 0.43 and $4.5 \mathrm{dS} \mathrm{m}^{-1}$, observing a reduction in the stem dry phytomass from $0.7 \mathrm{~g}$ to $0.1 \mathrm{~g}$, indicating a reduction of $86 \%$ when increasing the electrical conductivity of the irrigation water from the lowest to the highest saline level. Cavalcante et al. (2009), in a study with the yellow passion fruit crop irrigated with saline water, verified that the stem dry phytomass was reduced with the increment of the salinity in the irrigation water.

The silicon doses negatively influenced the stem dry phytomass (Figure 1C), with a reduction of $4.73 \%$ for each increment of $25 \mathrm{~g}$, that is, with the increase in the doses of Si from 0 to $100 \mathrm{~g}$ plant $^{-1}$, there was a decrease of $18.95 \%\left(0.40 \mathrm{~g} \mathrm{plant}^{-1}\right)$ in the stem dry phytomass. Linhares (2019), studying silicon sources in the passion fruit crop, verified that the silicon sources did not provide increments for the stem dry mass, in Passiflora edulis. Such a situation may be related to how silicon is accumulated, especially in the leaves, the reason by which it is found in lower contents in the stem.

When analyzing the root dry phytomass (Figure 2A) of yellow passion fruit plants, a linear reduction is verified, with a decrease occurring as the salinity of the irrigation water was increased, with a reduction equivalent to $10.72 \%$ per unitary increment of the ECW. When comparing in relative terms, it is verified that the plants grown under water salinity of $3.1 \mathrm{dS} \mathrm{m}^{-1}$ had a decline in the RDP of $31.01 \%$ (0.47 $\left.\mathrm{g} \mathrm{plant}^{-1}\right)$ in relation to those grown under the lowest saline level $\left(0.3 \mathrm{dS} \mathrm{m}^{-1}\right)$. The decrease in root dry phytomass may be related to the 

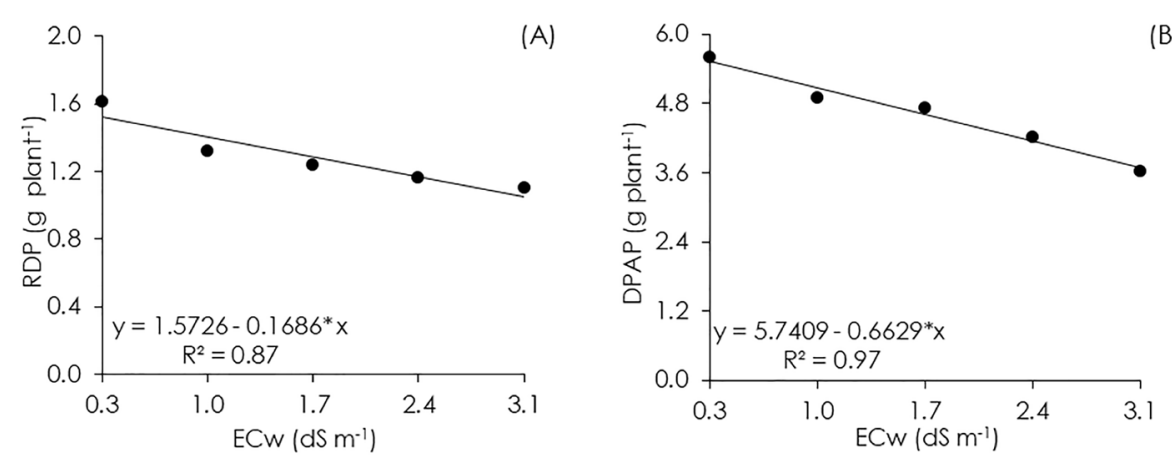

(B)

Figure 2. Root dry phytomass - RDP (A) and dry phytomass of aerial part - DPAP (B) in seedlings of the passion fruit cultivar 'Gigante Amarelo' as a function of saline levels of the irrigation water - ECW, at 60 days after sowing.

restriction of root elongation, highlighted as a tolerance mechanism of the genotype itself, reducing water absorption and, consequently, salt absorption as well, in order to mitigate toxicity (Moura et al., 2017).

The dry phytomass of aerial part of the passion fruit plants was also significantly affected by water salinity, with a linear decrease of $11.54 \%$ per unitary increment of the ECW, with a reduction of $33.49 \%$ in the DPAP of the plants irrigated with $\mathrm{ECW}$ of $3.1 \mathrm{dS} \mathrm{m}^{-1}$ in relation to those grown under water salinity of $0.3 \mathrm{dS} \mathrm{m}^{-1}$. Santos et al. (2016) report that the effect of the increment in salt concentration leads to shoot reduction in the plants due to the absence of osmotic adjustment, as an adaptation mechanism to salt excess in the soil solution. Santos et al. (2013) report that the reduction of phytomass production in the plants may be associated to the ionic and/or osmotic components of salt stress: with low water availability, the stomatal closure mechanism is activated, thus reducing the assimilation of $\mathrm{CO}_{2}$, a fact that directly affects the production of phytomass in the plants.

Likewise, Andrade (2018), studying the yellow passion fruit subjected to different irrigation water salinities $\left(0.7,1.4,2.1\right.$, and $\left.2.8 \mathrm{dS} \mathrm{m}^{-1}\right)$, verified decrease with per unit increase of the ECW equivalent to $17.86 \%$, $14.10 \%$, and $16.10 \%$ for the variables of dry phytomass of leaves, stem dry phytomass, and shoot dry phytomass, at 205 days after transplantation.

According to the analysis of variance, a significant effect of the saline levels is verified on the root/shoot (R/S) ratio, total dry phytomass (TDP), and Dickson quality index (DQI) of the passion fruit seedlings, at 60 DAS. The silicon doses significantly affected only the R/S ratio. There was no interaction between the factors (SL XSD) on any of the analyzed variables, at 60 days after sowing (Table 3).

The root/shoot ratio of the passion fruit plants (Figure 3A) was significantly affected by water salinity, with a linear growing behavior as the salinity levels of the irrigation water were increased, whose increment was equivalent to $36.08 \%$ per unitary increment of the ECW, that is, an increment of $91.16 \%\left(0.227 \mathrm{~g} \mathrm{plant}^{-1}\right)$ in the plants that received the highest saline level $\left(3.1 \mathrm{dS} \mathrm{m}^{-1}\right)$ in relation to those that received the lowest saline level $\left(0.3 \mathrm{dS} \mathrm{m}^{-1}\right)$.

This result demonstrates that the shoot part of the plants presents greater sensitivity to salinity increase in relation to the root system, being important for the optimization of the absorption process of water and nutrients since salinity causes stresses, limiting plant growth and development, considering that the reduction of growth parameters results from defense strategies of the plant itself, such as the decrease of cell turgidity, and metabolic and biochemical processes of the plant (Lima et al., 2014). In a study performed by Cavalcante et al. (2009) with the yellow passion fruit crop irrigated with saline water at concentrations from 0.4 to $4.0 \mathrm{dS} \mathrm{m}^{-1}$, it was verified that the $R / S$ ratio decreased with the increase in the electrical conductivity of the irrigation water.

Table 3. Summary of the analysis of variance for the root/shoot $(\mathrm{R} / \mathrm{S})$ ratio), total dry phytomass (TDP), and Dickson Quality Index (DQI) of plants of the passion fruit cultivar 'Gigante Amarelo' grown under different salinity levels of the irrigation water and silicon doses, at 60 days after sowing (DAS).

\begin{tabular}{lcccc}
\hline \multirow{2}{*}{ Source of variation } & \multirow{2}{*}{ DF } & \multicolumn{3}{c}{ Mean squares } \\
\cline { 3 - 5 } & & $\mathrm{R} / \mathrm{S}$ & $\mathrm{TDP}$ & $\mathrm{DQI}$ \\
\hline Saline levels (SL) & 4 & $0.16^{*}$ & $17.31^{*}$ & $0.03^{*}$ \\
Linear regression & 1 & $0.63^{*}$ & $67.33^{*}$ & $0.14^{*}$ \\
Quadratic regression & 1 & $0.01^{\text {ns }}$ & $0.12^{\text {ns }}$ & $0.00001^{\text {ns }}$ \\
Silicon doses (SD) & 4 & $0.07^{* *}$ & $0.94^{\text {ns }}$ & $0.001^{\text {ns }}$ \\
Linear regression & 1 & $0.34^{*}$ & $14.49^{*}$ & $0.02^{* *}$ \\
Quadratic regression & 1 & $0.04^{\text {ns }}$ & $0.06^{\text {ns }}$ & $0.003^{\text {ns }}$ \\
Interaction (SL x SD) & 16 & $0.03^{\text {ns }}$ & $3.50^{\text {ns }}$ & $0.006^{\text {ns }}$ \\
Blocks & 3 & $0.41^{\text {ns }}$ & $0.09^{\text {ns }}$ & $0.007^{\text {ns }}$ \\
Residue & 72 & 0.01 & 0.64 & 0.005 \\
CV (\%) & & 24.49 & 13.58 & 20.29 \\
\hline ns:** reppectively not significant significant & &
\end{tabular}

ns, *, **, respectively not significant, significant at $p<0.05$ and $p<0.01$; DF - Degree of freedom; CV - Coefficient of variation. 

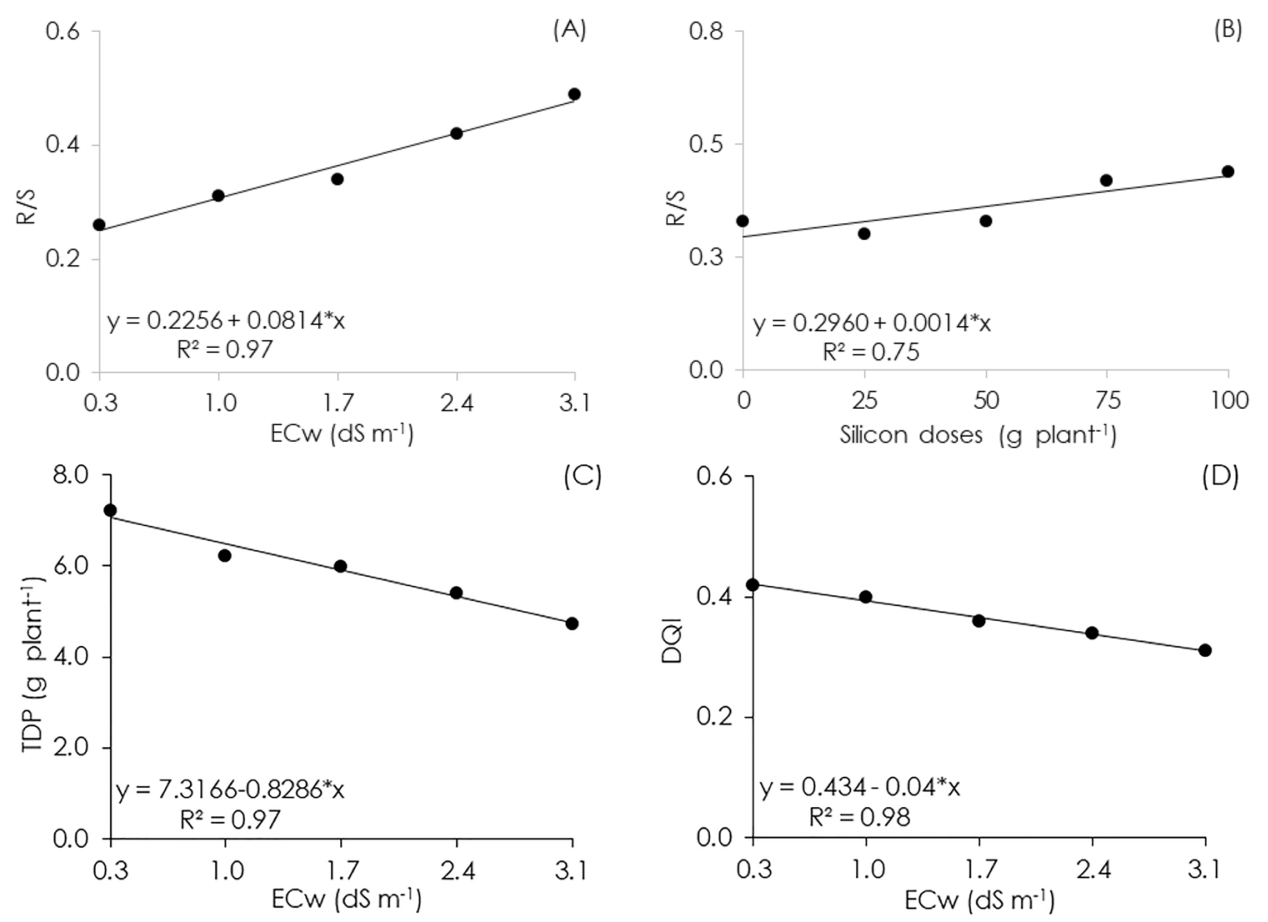

Figure 3. Root/shoot (R/S) ratio as a function of water salinity levels - ECW (A) and silicon doses (B); total dry phytomass (TDP) (C) and Dickson Quality Index - DQI (D) in plants of the passion fruit cultivar 'Gigante Amarelo' as a function of water salinity levels - ECW, at 60 days after sowing.

Regarding the effect of silicon fertilization on the $R / S$ ratio (Figure $3 B$ ), a linear growing behavior was verified, with an increment of $11.82 \%$ for each increase of $25 \mathrm{~g} \mathrm{plant}^{-1}$ in the silicon dose. The increase of the root/ shoot ratio is featured as a tolerance strategy for the plant, since, when subjected to stresses, they tend to enlarge their roots in search of water and nutrients, in accordance to Methrabanjoubani et al. (2015), who, when evaluating the effect of silicon application in cotton, canola, and wheat verified that all plants grown in the presence of $\mathrm{Si}$, at the dose of $1.5 \mathrm{mmol} \mathrm{L}^{-1} \mathrm{Si}$ for 12 days, presented longer roots when compared to the plants grown in the absence of Si.

A study performed by Souza (2015) evidenced that the passion fruit plants accumulate silicon primarily in the roots instead of leaves and stem, which indicates that this element, in the roots, performs a role in the signaling network, being able to induce systemic resistance in other organs.

For the total dry phytomass of passion fruit seedlings (Figure 3C), a linear decrease is verified with the increase in the water salinity levels, occurring a reduction of $11.32 \%$ per unitary increment of the ECW, that is, a decline in the TDP of $32.82 \%$ ( $\left.2.32 \mathrm{~g} \mathrm{plant}^{-1}\right)$ in the plants grown under the highest saline level $\left(3.1 \mathrm{dS} \mathrm{m}^{-1}\right)$ in relation to those that received the lowest saline level $\left(0.3 \mathrm{dS} \mathrm{m}^{-1}\right)$. The decrease in the total dry phytomass, under salt stress conditions, may be associated to an osmotic adjustment attempt by the plant, with the detachment of energy for the accumulation of sugars, organic acids, and ions in the vacuole, energy that would be used for phytomass accumulation in the plant (Santos et al., 2013). The results obtained in the present study corroborates with Andrade et al. (2018), who in a study evaluating the growth of yellow passion fruit plants as a function of the salinity of the irrigation water - ECW $\left(0.7,1.4,2.1\right.$, and $\left.2.8 \mathrm{dS}^{-1}\right)$, verified a linear decrease in the accumulation of leaf, stem, and total dry phytomass of $113.64,78.78$, and $192.41 \mathrm{~g}^{\text {plant }}{ }^{-1}$, respectively, when subjected to the highest saline level.

For the Dickson Quality Index (Figure 3D), a linear decreasing behavior is observed as a function of the increase in water salinity, with a reduction of $9.21 \%$ per unitary increment of the ECW, that is, the passion fruit plants irrigated with $\mathrm{ECW}$ of $3.1 \mathrm{dS} \mathrm{m}^{-1}$ obtained a reduction in the $D Q$ I of $26.54 \%$ compared to the plants that received the lowest level $\left(0.3 \mathrm{dS} \mathrm{m}^{-1}\right)$. In spite of the reduction in the DQI with the increase in water salinity, the passion fruit seedlings, when subjected to the ECW of 3.1 dS $\mathrm{m}^{-1}$, presented an DQI of 0.31 , an important fact from the point of view that, even under salt stress conditions, the passion fruit seedlings presented an DQI above 0.2, and thus considered as of good final quality for field establishment. Corroborating the results of the present study, Moura et al. (2017), in a study performed with the formation of seedlings of the genus Passiflora under salt stress $\left(0.3,1.4,2.5,3.6\right.$, and $\left.4.7 \mathrm{dS}^{-1}\right)$, obtained an DQI 
value above 0.2 when the plants were irrigated with ECW

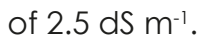

\section{Conclusions}

Salt stress values above $0.3 \mathrm{dS} \mathrm{m}^{-1}$ cause the decrease of phytomass production in passion fruit seedlings at 60 days after sowing, highlighting the dry phytomass of leaves as the most sensitive variable. In spite of the reduction in phytomass accumulation, it is possible to produce passion fruit seedlings under water salinity of $3.1 \mathrm{dS} \mathrm{m}^{-1}$ with a Dickson quality index equivalent to 0.31 considered acceptable.

The doses of silicon fertilization resulted in a greater root/shoot ratio in seedlings of the passion fruit cultivar 'Gigante Amarelo'.

\section{References}

Andrade, E.M.G. 2018. Águas salinas e aplicação foliar de peróxido de hidrogênio no cultivo de maracujazeiro amarelo. 104f. (D.SC. Thesis) - Federal University of Campina Grande, Campina Grande, Brazil.

Andrade, E.M.G., Lima, G.S., Lima, V.L.A., Silva, S.S., Gheyi, H.R., Silva, A.A.R. 2019. Gas exchanges and growth of passion fruit under saline water irrigation and $\mathrm{H}_{2} \mathrm{O}_{2}$ application. Revista Brasileira de Engenharia Agrícola e Ambiental 23: 945-951.

Andrade, J.R., Medeiros, A.S., Maia Júnior, S.O., Rezende, L.P., Araújo Neto, J.C. 2018. Germination and morphophysiology of passion fruit seedlings under salt water irrigation. Pesquisa Agropecuária Tropical 48: 229236.

Ayers, R.S., Westcot, D.W. 1999. A qualidade da água na agricultura. UFPB, Campina Grande, Brazil. 153 p.

Bernardo, S., Soares, A.A., Mantovani, E.C. 2006. Manual de irrigação. UFV, Viçosa, Brazil. 625 p.

Cavalcante, L.F., Sousa, G.G., Gondim, S.C., Figueiredo, F.L., Cavalcante, I.H.L., Diniz, A.A. 2009. Crescimento inicial do maracujazeiro amarelo manejado em dois substratos irrigados com água salina. Irriga 14: 504-517.

Cavalcanti, J.C.P. 2008. Recomendações de adubação para o estado Pernambuco (2a aproximação). 3.ed. Instituto agronômico do Pernambuco, Recife, Brazil. 212 p.

Dickson, A., Leaf, A.L., Hosner, J.F. 1960. Quality appraisal of white spruce and white pine seedling stock in nurseries. The Forest Chronicle 36: 10-13.

Ferreira, D.F. 2011 . Sisvar: A computer statistical analysis system. Ciência e Agrotecnologia 35: 1039-1042.

Freire, A.L.O., Saraiva, V.P., Miranda, J.R.P., Bruno, G.B. 2010. Crescimento, acúmulo de íons e produção de tomateiro irrigado com água salina. Semina: Ciências Agrária 31: 1133-1144.
Lima, G.S., Nobre, R.G., Gheyi, H.R., Soares, L.A.A., Lourenço, G.S., Silva, S.S. 2014. Aspectos de crescimento e produção da mamoneira irrigada com águas salinas e adubação nitrogenada. Revista Brasileira de Engenharia Agrícola e Ambiental 6: 615-622.

Linhares, G.A.N. 2019. Fontes de silício em mamoeiro e maracujazeiro: crescimento, fisiologia e indução de resistência. 107f. (D.Sc. Thesis) - State University of the North Fluminense Darcy Ribeiro, Rio de Janeiro, Brazil.

Meletti, L.M.M. 2011 . Avanços na cultura do maracujá no Brasil. Revista Brasileira de Fruticultura 33: 83-91.

Methrabanjoubani, P., Abdolzadeh, A., Sadeghipour, H.R., Aghdasi, M. 2015. Silicon affects transcellular and apoplastic uptake of some nutrients in plants. Pedosphere 25: 192-201.

Moura, R.S., Gheyi, H.R., Coelho Filho, M.A., Jesus, O.N., Lima, L.K., Cruz, C.S. 2017. Formation of seedlings of species from the genus Passiflora under saline stress. Bioscience Journal 33: 1197-1207.

Nascimento, E.S., Cavalcante, L.F., Gondim, S.C., Souza, J.T.A., Bezerra, F.T., Bezerra, M.A.F. 2017. Formação de mudas de maracujazeiro amarelo irrigadas com águas salinas e biofertilizantes de esterco bovino. Revista Agropecuária Técnica 38: 1-8.

Oliveira, F.T., Hafle, O.M., Mendonça, V., Moreira, J.N., Júnior, E.B.P. 2013. Fontes orgânicas e volumes de recipiente no crescimento inicial de porta-enxertos de goiabeira. Revista Verde de Agroecologia e Desenvolvimento Sustentável 07: 97-103.

Richards, L.A. 1954. Diagnosis and improvement of saline and alkali soils. USDA, Washington, USA. 160 p.

Santos, D.P., Santos, C.S., Silva, P.F., Pinheiro, M.P.M.A., Santos, J.C. 2016. Crescimento e fitomassa da beterraba sob irrigação suplementar com água de diferentes concentrações salinas. Revista Ceres 63: 509-516.

Santos, L.A.A., Lima, G.S., Nobre, R.G., Gheyi, H.R., Pereira, F.H.F. 2013. Fisiologia e acúmulo de fitomassa pela mamoneira submetida a estresse salino e adubação nitrogenada. Revista Verde de Agroecologia e Desenvolvimento Sustentável 8: 247:256.

Santos, J.B. 2001. Estudo das relações nitrogênio: potássio e cálcio: magnésio sobre o desenvolvimento vegetativo e produtivo do maracujazeiro amarelo. 88f. (M.Sc. Thesis) - Federal University of Paraíba, Areia, Brazil.

Souza, B.N. 2015. Silício no desenvolvimento morfofisiológico de mudas de maracujazeiro amarelo. 79f. (M.Sc. Thesis) - Federal University of Lavras, Lavras, Brazil.

Souza, P.S., Nobre, R.G., Silva, E.M., Lima, G.S., Pinheiro, F.W.A., Almeida, L.L.S. 2016. Formation of 'Crioula' guava rootstock under saline water irrigation and nitrogen doses. Revista Brasileira de Engenharia Agrícola e Ambiental 20: 739-745. 
Teixeira, P.C., Donagemma, G.K., Fontana, A., Teixeira, W.G. (ed.) 2017. Manual de métodos de análise de solo. 3. ed. Embrapa, Brasília, Brazil. 573 p.

Conflict of Interest Statement: The authors declare that the research was conducted in the absence of any commercial or financial relationships that could be construed as a potential conflict of interest.

All the contents of this journal, except where otherwise noted, is licensed under a Creative Commons Attribution License attribuition-type BY. 